\title{
Factors of Online Learning Model to Enhance Knowledge Construction in Multicultural Society for Workers Competencies in Southernmost Provinces of Thailand
}

\author{
Anuchit Ngamkajornwiwat, Wasant Atisabda, and Ophat Kaosaiyaporn
}

\begin{abstract}
This study aimed to analyze factors of online learning model to enhance knowledge construction in multicultural society for workers competencies in industrial factories in three southernmost provinces of Thailand. The sample consisted of 162 factory administrators, work supervisors, human resource developers, technology innovators, and the study was divided into two phases: the first phase was to analyze and synthesize literature related to the online learning model to enhance knowledge construction in multicultural society for workers competencies, and the second phase was to analyze factors for the online learning model to enhance knowledge construction in multicultural society for workers competencies in industrial factories in three southernmost provinces of Thailand. The findings revealed six factors: 1) Factor of learning activities design on the online learning, 2) Factor of process for knowledge construction, 3) Factor of support and management of online learning, 4) Factor of administration and management system of online learning, 5) Factor of Knowledge Inquiry method, 6) Factor of communication tools.
\end{abstract}

Index Terms-Online learning, knowledge construction, workers competencies, multicultural education.

\section{INTRODUCTION}

The southernmost provinces of Thailand, Pattani, Yala, Narathiwat, and Satun are dominated by Malayu-speaking Muslims around $80 \%$ and the others are Buddhist Thais and Chinese Thais, while for whole country Buddhist Thais are the majority. Most Thai Muslims are Malay descent, reflecting the common cultural heritage Thailand's southernmost provinces share with Malaysia [1]. It is the land of multicultural society including Thai Muslim, southern Thai, and Chinese Thai to identify the uniqueness of the area. However, the southernmost Thai provinces are poorer than the rest of the country, and their main business sectors agriculture, fishing and tourism - have been hurt by the violence. Several thousand people have been killed in Muslim separatist unrest in the far south which flared in January 2004. Civilians bear the brunt of the violence [2]. In spite of the fact that there is the unrest situation in this area, people still live and work in peace and understand each other. In schools, colleges, workplace like government services, business and industrial factories, they have stayed and worked together in

Manuscript received November 30, 2017; revised January 9, 2018. This work was supported in part by Prince of Songkla University.

The authors are with the Department of Educational Technology, Faculty of Education, and Research Center for Educational Innovations and Teaching and Learning Excellence, Prince of Songkla University, Thailand (e-mail: anuchit.ng@gmail.com, vassan.a@psu.ac.th, ophat.k@psu.ac.th). peace and been taught to be aware of the cultural diversity. In workplace like in factories in the southernmost areas, it also reflects the multicultural society by Thai Muslims, Buddhist Thai, and Chinese Thai workers. The realization of cultural diversity has strengthened the economic development as well as social development [3]-[5].

The human resource development (HRD) is very important for the organization in the modern world in order to keep up with changes in the 21st century. Three southernmost provinces in Thailand including Pattani, Yala, and Narathiwas are the land of multicultural society including Thai Muslim, southern Thai, and Chinese Thai to identify the uniqueness of this area. Thai Muslims are the majority of $80 \%$. Therefore, the multicultural issues are crucial in this area to support and strengthen the community with cultural diversity.

In the knowledge-based society and in the 21st century society, the society needs not only the labor from our employees, but also their competencies to work in the modern world. All workers and employees need to be developed their competency in working as well as the ways of life. On the job training is not limited to the face-to-face workshop, but the new technology can create the new learning environment for them "to work and to learn" and "to learn and to work". Technology innovation will be implemented in HRD in work place.

This study intended to propose a model of online learning to support the workers based on the knowledge construction in three southernmost provinces in Thailand as well as to foster the way of life in cultural diversity and to support and increase the working competencies and the quality of lives of workers and people who live and work in the factories in the sensitive areas of the southernmost provinces of Thailand.

\section{THE PURPOSES OF STUDY}

This study is to analyze factors of online learning model to enhance knowledge construction in multicultural society for workers competencies in industrial factories in three southernmost provinces of Thailand.

\section{RESEARCH METHODOLOGY}

The research method consisted of two phases:

Phase I - to analyze and synthesize the literature and documents related to the development of a factors of online learning model to enhance knowledge construction in multicultural society for workers competencies in industrial 
factories in three southernmost provinces of Thailand. Those included the concepts, principles, theories, and researches on technology innovation and multicultural education in workers competencies.

Phase II - To analyze the factors of online learning model to enhance knowledge construction in multicultural society for workers competencies in industrial factories in three southernmost provinces of Thailand.

This phase included two stages:

1) To create the variable factors for a online learning model in five areas:

- Knowledge construction

- Distance education

- Cultural diversity

- Multicultural education

- Online learning of workers competencies in industrial factories.

Based on the experts' opinion on the suitable components and processes (Variables) pertaining to a online learning model for multicultural classrooms, the following steps were:

a) Create a table allowing experts to analyze and rate each variable,

b) Assess the expert responses in this table,

c) Use the information obtained from the experts' opinions phase to develop the questionnaire, and

d) Assess the quality of the questionnaire for reliability by content validity and a pilot study using the alpha coefficient.

2) To analyze the factors using factor analysis with the principal component analysis. The researchers selected the subjects in the workers who work in industrial factories to develop a variable at factor loading of .50 or higher. A factor should include at least three variables to be considered as the factor.

\section{RESEARCH RESULT}

1) The samples consisted of 162 factory administrators, work supervisors, human resource developers, technology innovators in southern part of Thailand. It included: the majority of sample were female $(n=106 ; 66 \%)$; The majority were around $31-40$ years old $(n=61 ; 43 \%)$; the majority of the sample group possess a master degree $(\mathrm{n}=87 ; 61 \%)$; and working experiences for $6-10$ years $(46 \%)$.

2) The factor analysis revealed as follows:

- Hypothesis testing in correlation matrix method by Bartlett's test of Sphericity was significantly at the low level $(\mathrm{sig}=.0000)$.

- Analysis and comparison of Bartlett's Test of Sphericity size by using KMO (The Kaiser-Meyer-Olkin) or measure of sampling adequacy were at .916 which meant that the data was closed to 1 and indicated that those were more suitable for analysis.

3) The analysis of factors for a online learning model to enhance knowledge construction in multicultural society for workers competencies in industrial factories in three southernmost provinces of Thailand implemented the principal component analysis technique. The result revealed that a model had six factors with 73.089 percentage of variance.

4) This analysis was based on Orthogonal rotation by varimax method with factor loading of .50 or higher lead to six factors with thirty five variables as follows:

- Factor one: the learning activities design on the online learning - has ten variables with weight of .866-.512.

- Factor two: the process of knowledge construction - has eight variables with weight of .737-.574.

- Factor three: the support and management of online learning - has six variables with weight of .736-.552.

- Factor four: administration and management system of online learning - has five variables with weight of .712-.565.

- Factor five: the knowledge inquiry method - has three variables with weight of $.687-.620$.

- Factor six: the communication tools - has three variables with weight of $.839-.590$.

TABLE I: THE FACTORS OF ONLINE LEARNING MODEL TO ENHANCE KNOWLEDGE CONSTRUCTION IN MULTICULTURAL SOCIETY FOR WORKERS COMPETENCIES IN INDUSTRIAL FACTORIES IN THREE SOUTHERNMOST PROVINCES OF THAILAND (LOADING DETAIL)

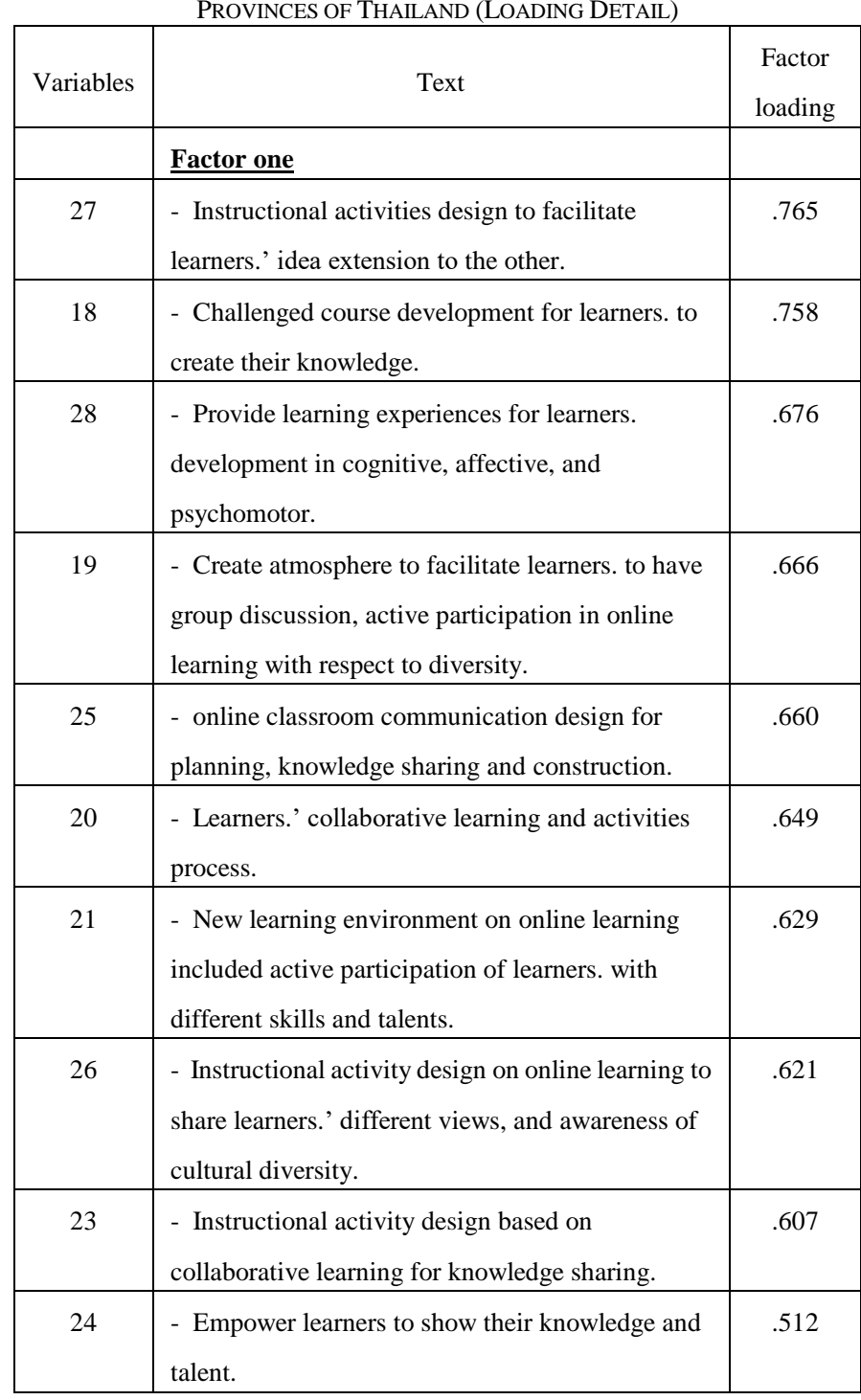




\begin{tabular}{|c|c|c|c|c|c|}
\hline Variables & Text & $\begin{array}{l}\text { Factor } \\
\text { loading }\end{array}$ & Variables & Text & $\begin{array}{l}\text { Factor } \\
\text { loading }\end{array}$ \\
\hline & Factor two & & & & \\
\hline \multirow[t]{2}{*}{8} & \multirow{2}{*}{$\begin{array}{l}\text { - Integrate the social experiences in learning } \\
\text { process. }\end{array}$} & \multirow[t]{2}{*}{.737} & & $\underline{\text { Factor five }}$ & \\
\hline & & & 17 & - Inquiry is the key issue of online learning process. & .687 \\
\hline 6 & $\begin{array}{l}\text { - Link learners.' external experiences with } \\
\text { classroom experiences. }\end{array}$ & .674 & 38 & $\begin{array}{l}\text { - Goal of learning should be based on learners' } \\
\text { needs; accordingly, inquiry-based learning should }\end{array}$ & .671 \\
\hline \multirow[t]{2}{*}{5} & \multirow{2}{*}{$\begin{array}{l}\text { - Promote Knowledge construction experiences for } \\
\text { learners. }\end{array}$} & \multirow[t]{2}{*}{.644} & & be promoted in online learning. & \\
\hline & & & \multirow[t]{2}{*}{16} & \multirow{2}{*}{$\begin{array}{l}\text { - Encourage learners to search for instructional } \\
\text { resources. }\end{array}$} & \multirow[t]{2}{*}{.620} \\
\hline \multirow[t]{2}{*}{4} & \multirow[t]{2}{*}{ - Encourage the critical thinking. } & \multirow[t]{2}{*}{.618} & & & \\
\hline & & & & Factor six & \\
\hline 2 & - Indentify the meaningful context for learners. & .601 & 34 & $\begin{array}{l}\text { - Webboard is a tool for learners to communicate } \\
\text { and create an online community. }\end{array}$ & .839 \\
\hline \multirow[t]{2}{*}{3} & \multirow{2}{*}{$\begin{array}{l}\text { - Link the experiences on online learning to the } \\
\text { real world. }\end{array}$} & \multirow[t]{2}{*}{.597} & & & \\
\hline & & & \multirow[t]{2}{*}{36} & \multirow{2}{*}{$\begin{array}{l}\text { - Communication through chat rooms is important } \\
\text { for creating an online social network. }\end{array}$} & \multirow[t]{2}{*}{.605} \\
\hline 7 & $\begin{array}{l}\text { - Diverse the learning experiences for new vision } \\
\text { of learners. }\end{array}$ & .595 & & & \\
\hline \multirow[t]{2}{*}{9} & $\begin{array}{l}\text { - Interpolate the social experiences into the } \\
\text { learning process. }\end{array}$ & .574 & \multirow[t]{2}{*}{35} & \multirow{2}{*}{$\begin{array}{l}\text { - Reflective Journal is a tool for learners } \\
\text { communicate and exchange knowledge, ideas, and } \\
\text { attitudes. }\end{array}$} & \multirow[t]{2}{*}{.590} \\
\hline & Factor three & & & & \\
\hline
\end{tabular}

In the Table I showed that the factor loading detail of Online learning model to enhance knowledge construction in multicultural society for workers competencies in industrial factories in three southernmost provinces of Thailand

\section{CONCLUSIONS}

In conclusion, the results of this study revealed that the Factors can be grouped into 6 sets as follows:

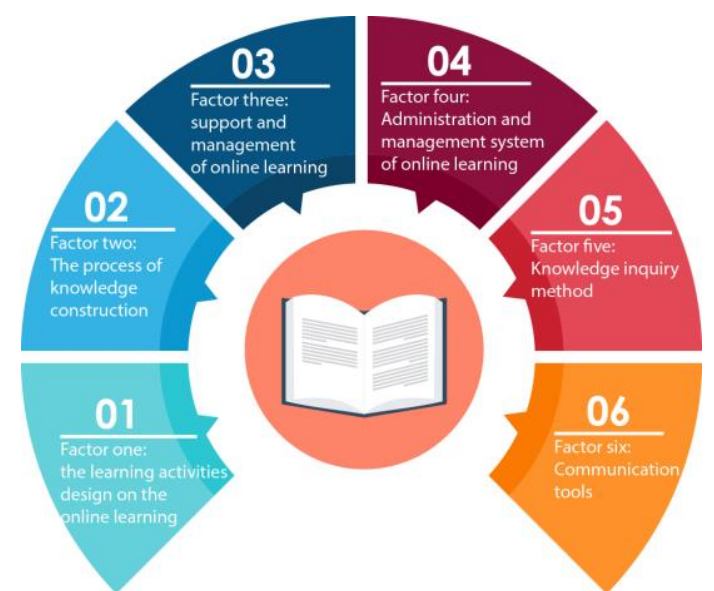

Fig. 1. Online learning model to enhance knowledge construction in multicultural society for workers competencies in industrial factories in three southernmost provinces of Thailand.

In Fig. 1 the Online learning model to enhance knowledge construction in multicultural society for workers competencies in industrial factories in three southernmost provinces of Thailand was presented. The model composed of 6 components: 1) the learning activities design on the online learning for on-the-job training. 2) the process of knowledge 
construction from workers' working experiences, 3) the support and management of online learning to facilitate the learning process, 4) the administration and management system of online learning for quality development, 5) the knowledge inquiry method for the continuous improvement, and 6) the communication tools based on electronic tools, e.g. social media, blog, forum, etc.

Factor one: the learning activities design on the online learning was a factor that focused on the new learning environment and instructional activities used in the online learning. It should support the diverse learning styles as well as the community of practices and scholars.

The teacher should design and develop the challenged course for learners to create their knowledge by including both cooperative and communicative learning activities. The learners could clearly explain what they have learned from task and problem learning activities. Moreover, The awareness of cultural diversity should be included in the online learning.

Factor two: The process of knowledge construction and tracking learner progress focuses on the actual learning situation and the actual problem-solving context by using social experience to enhance the learning process, and encourage critical thinking. A variety of techniques were used to build deep experiences and broaden learners' views. An evaluation process to monitor learners during these activities is important.

Factor three: support and management of online learning was a factor in designing an environment to setup the activities on online learning. The virtual social network skills on online classroom could be established by giving the learners opportunities to write or create a project where each student could add their own story or extend the story of others. The learners could share stories within a topic and could then search for different points of view and practice the cooperating for sharing and learning activities.

Factor four: Administration and management system of online learning was a factor to management and security system that supports operational activities and data collection. For example, the learner achievement record can help the lecturer or facilitator in planning and managing the class and activities and also in analyzing the learners' achievement. The class attendance statistic records can be used for tracking the learning behavior and activities of the learners within the virtual social network. The evaluation system can be used to monitor learners during and after the mission and to determine the effectiveness of the various media-types being used.

Factor five: Knowledge inquiry method was a factor to encourage the learners to inquire resources for supporting learning activities on their class. The target of learning should be based on the learners. Accordingly, the teacher or facilitator should have designed the inquiry approach in the online learning.

Factor six: Communication tools were a factor for communicating on social artifacts. The tools could enable the learners to link to the social networks to communicate with other learners from different places. It aimed to encourage the learners to build up their social network on online learning. The communication tools consisted of webboard, chatroom or reflective journal, etc.

\section{RECOMMENDATIONS}

\section{A. Recommendations for the Research Application}

The Factors are flexible and can be modified to proper situation, learners, subjects and objectives of learning.

\section{B. Recommendations for the Next Research}

1) Make the Factors more complete, research and develop learning media to encourage both synchronous and asynchronous online learning activities.

2) Develop the Factors to cover the basic education which is an early preparation for teacher learners in being the member of ASEAN economic community.

\section{REFERENCES}

[1] Ministry of Foreign Affairs. (2011). National Report Submitted in Accordance with Paragraph of The Annex to the Human Rights Council Resolution. [Online]. Available: http://www.mfa.go.th/ humanrights/images/stories/UPREng30Dec11.pdf

[2] Thompson Reuter Foundattion. (2013). Violence in southernthailand. [Online]. Available: http://www.trust.org/spotlight/Thailandssou thern-violence/ ?tab=briefing

[3] C. Chidchanok et al., "Instructional system design for worker education in multicultural and knowledge-based society," Procedia Social and Behavioral Sciences, vol. 174, pp. 2355-2360, 2015.

[4] C. Chidchanok et al., "A learning innovation model for increasing workers competencies in industrial factories in three southernmost provinces of Thailand," International Journal of Information and Education Technology, vol. 5, no. 6, pp.447-450, 2015.

[5] Y. Banyat. (2008). The encouragement a children development in the context of cultural diversity. [Online]. Available: http://www.cf. mahidol.ac.th/ autopage/file/WedJuly2008-22-18-5-4articel-004.pdf

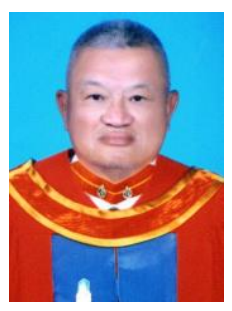

Anuchit Ngamkajonviwat is the CEO of Pattani Concrete Company in Thailand. He received the doctor of education in educational leadership and innovation, Faculty of Education, Prince of Songkla University, Thailand. He also graduated in M.A. (social development) from the National Institute of Development Administration (NIDA), Thailand and in B.A. (social development) from Yala Rajabhat University, Thailand.



Wasant Atisabda is an assistant professor at the Department of Educational Technology, Faculty of Education and the director of Research Center for Educational Innovations and Teaching and Learning Excellence, Prince of Songkla University, Thailand. $\mathrm{He}$ received B.Ed. in Teaching German as second language and M.Ed.in Audio-Visual Education from Chulalongkorn University, Thailand, and Ed.Sp. in Educational Technology and Ph.D. in Higher and Continuing Education from University of Missouri, USA.



Ophat Kaosaiyaporn is an assistant professor at the Department of Educational Technology, Faculty of Education, Prince of Songkla University, Thailand. He also serves as the Secretary of the Research Center for Educational Innovations and Teaching and Learning Excellence, Prince of Songkla University He received B.Ed. in art education, M.Ed. in educational technology and communications from Prince of Songkla University, Thailand, and Ph.D. educational communications and Technology from Chulalongkorn University, Thailand. 